\title{
Blue Rubber Bleb Naevus Syndrome and Chiari Malformation: High Risk of Peroperative Haemorrhage
}

\section{Mavi Süngersi Bleb Nevüs Sendromu ve Chiari Malformasyonu: Yüksek Peroperatif Kanama Riski}

\author{
Anuj BAHL ${ }^{1}$, Ashok RAGHAVAN ${ }^{2}$, Saurabh SINHA ${ }^{1}$ \\ ${ }^{1}$ Sheffield Children's Hospital, Department of Neurosurgery, Sheffield, United Kingdom \\ ${ }^{2}$ Sheffield Children's Hospital, Department of Neuroradiology, Sheffield, United Kingdom
}

Corresponding Author: Anuj BAHL / E-mail: anujbahl3@yahoo.co.uk

\begin{abstract}
Blue rubber bleb naevus syndrome is an uncommon disorder whereby patients possess cutaneous vascular malformations. Cranial malformations have been rarely reported in the literature. We report the first ever case of a patient with blue rubber bleb naevus syndrome (BRBNS), who was found to have a symptomatic Chiari malformation and prominent subcutaneous vascular malformations in communication with the intracranial venous sinuses. In our case, a routine operation for Chiari malformation was complicated by significant blood loss. The operative hazards are presented along with suggested peri-operative management strategies when carrying out neurosurgical operations on patients with BRBNS. A brief literature review is included.
\end{abstract}

KEYWORDS: Blue rubber naevus syndrome, Chiari malformation, Foramen magnum decompression, Vascular malformation

öz

Mavi süngersi bleb nevüs sendromu hastalarda kütanöz vasküler malformasyonlar bulunan nadir bir bozukluktur. Kraniyal malformasyonlar literatürde nadiren bildirilmiştir. İntrakraniyal venöz sinüslerle iletişim halinde belirgin subkütan vasküler malformasyonları ve semptomatik Chiari malformasyonu olduğu saptanan mavi süngersi bleb nevüs sendromu olan ilk hastayı sunuyoruz. Olgumuzda Chiari malformasyonu için rutin bir ameliyat önemli kan kaybı ile komplike oldu. Mavi süngersi bleb nevüs sendromlu hastalarda nöroşirürjik ameliyatlar yaparken operatif tehlikeler, önerilen perioperatif yönetim stratejileriyle birlikte sunulmaktadır. Kısa bir literatür derlemesi dahil edilmiştir.

ANAHTAR SÖZCÜKLER: Mavi süngersi nevüs sendromu, Chiari malformasyonu, Foramen magnum dekompresyonu, Vasküler malformasyon

\section{INTRODUCTION}

Blue rubber bleb naevus syndrome (BRBNS) is an uncommon disorder whereby patients possess cutaneous vascular malformations that are blue and rubbery to palpation, and they may also possess gastrointestinal vascular malformations presenting with anaemia (1). Other organs rarely involved are the brain, liver, lungs and skeletal muscle (3). We present a case of a 14-year old girl with known blue rubber bleb naevus syndrome who was found to have a symptomatic Chiari malformation. She also had prominent vascular malformations involving the subcutaneous tissues in the posterior aspect of the cervical spine, which were draining the left sigmoid sinus. To our knowledge this association has never been reported previously and has serious implications for pre-operative preparations for these patients.

\section{CASE REPORT}

\section{History and Presentation}

A 14-year-old right-handed girl presented with right-sided tinnitus and impulse headaches for the past year. She had also been complaining of reduced hearing in her left ear and was deaf in the right ear since birth. Examination revealed several scattered blue blebs on her body. A salmon-coloured telangiectatic naevus was noted on the back of the neck from the occipital protuberance to $\mathrm{C} 4$. Neurological examination was normal. She had previously been diagnosed with BRBNS as an infant on the basis of cutaneous stigmata of the syndrome. At 6 months of age, the patient had undergone repair of a ventricular septal defect. More recently two separate skin naevi had been removed using sclerotherapy. The patient's mother also had BRBNS.

1.5 T MR imaging (GE medical systems, Milwaukee, USA) revealed prominent vascular malformations involving the subcutaneous tissues of the posterior neck and also around the posterior pharynx and the longus colli muscles. MR digital subtraction angiography however was grossly normal with no evidence of shunting thereby ruling out an AVM. Although MR venography was not carried out, the MRI revealed a 
prominent enlarged left sigmoid sinus, which was felt to be draining into the posterior soft tissues (Figure 1). There was a type I Chiari malformation noted with tonsillar descent to the mid C2 vertebra. Syringomyelia was noted in the lower cervical and mid thoracic region (Figure 2).
After appropriate counselling, we offered craniocervical decompression for the Chiari malformation. Routine blood work-up was normal.

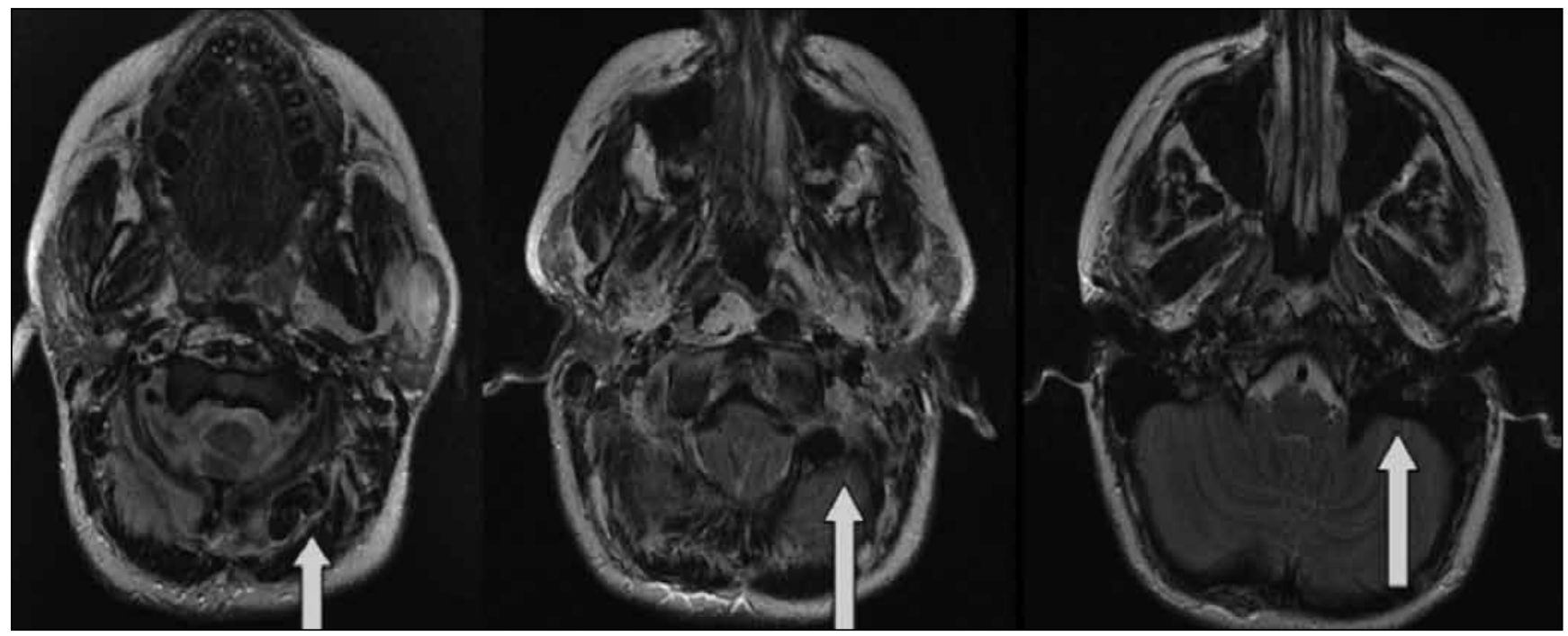

Figure 1: Axial T2 images showing prominent vessels in the sub occipital region on the left side draining via an anomalous draining vein into the left sigmoid sinus.

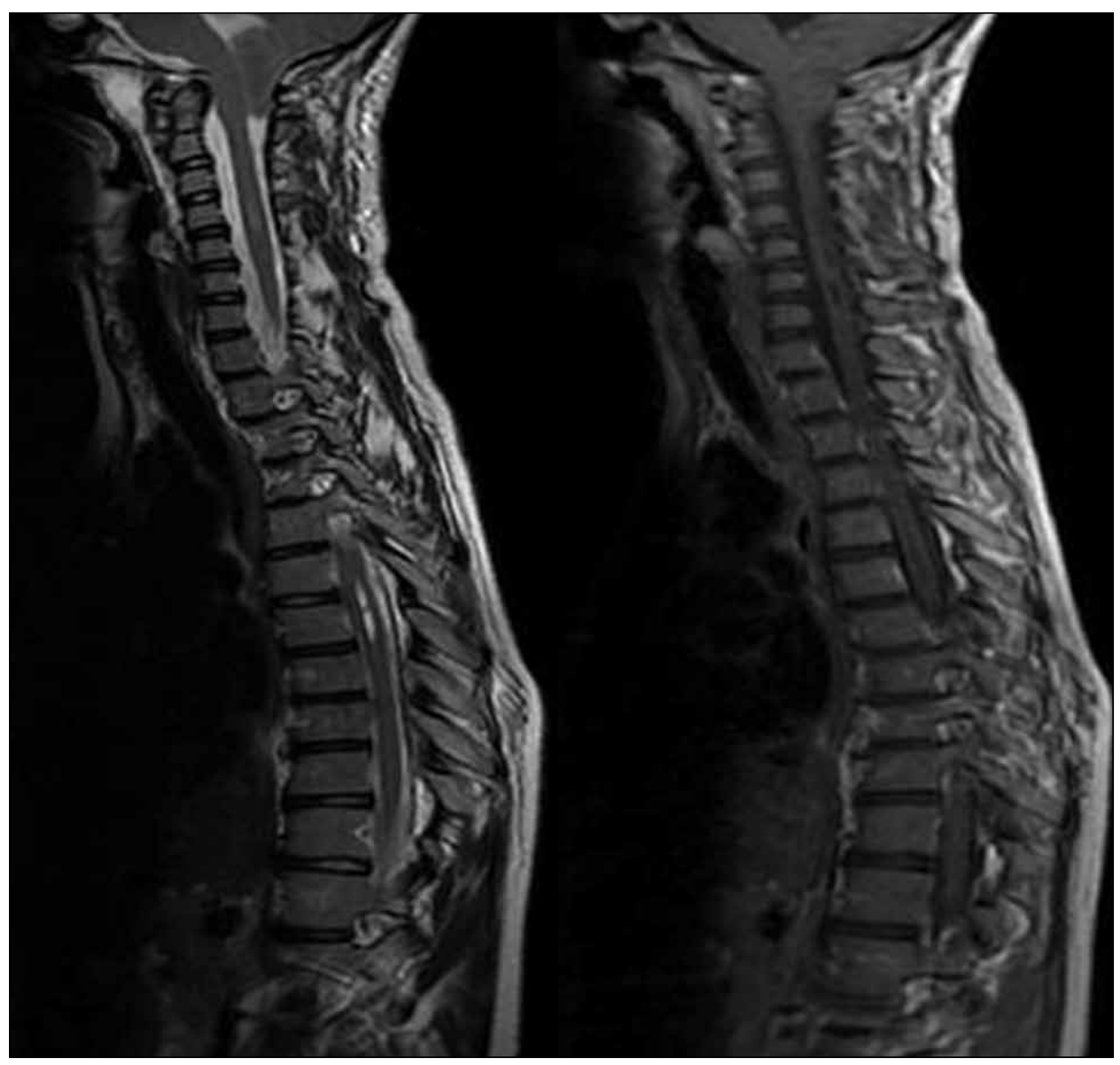

Figure 2: Sagittal T2 and T1 images showing the Chiari 1 malformation with syringomyelia. 


\section{Operative Procedure}

The patient was placed prone and a midline approach was carried out. There was significant bleeding from superficial tissues and the musculature whereby $900 \mathrm{mls}$ of blood was lost. Haemostasis required a combination of diathermy, Ligaclips $^{\mathrm{TM}}$ (Ethicon Inc., Somerville, NJ, USA) and Floseal ${ }^{\circ}$ (Baxter Inc, Deerfield, IL, USA), a haemostatic matrix sealant. Bony decompression followed by further soft tissue release at the craniocervical junction was uneventful. Ultrasound revealed good CSF flow at the craniocervical junction and thus durotomy was not carried out. Two units of packed red blood cells were transfused intra-operatively.

\section{Postoperative Course}

The patient had an uneventful immediate post-operative course. She was discharged 4 days post-operatively. The patient was re-admitted 10 days later with a superficial wound infection, necessitating wound debridement and a 2-week course of antibiotics. There were no untoward events with haemostasis at the second operation. When seen after 6 weeks at the outpatient clinic, the patient's headaches had abated completely. The wound had healed nicely and the patient was well.

\section{DISCUSSION}

Patients with BRBNS found to have a Chiari malformation are rare (6). Intracranial venous anomalies have previously been reported in children and as a delayed diagnosis in the adult population (4). Our case was unusual in that the aberrant left sigmoid sinus was draining into the soft tissues of the posterior cervical spine. The intracranial venous drainage was not, however, being shunted to the soft tissues. As the coagulation profile was normal we proceeded with surgery but required the use of additional intra-operative aids to stop haemorrhage. The use of interferon-a and intravenous steroids pre-operatively has been reported in the literature, particularly in the setting of gastrointestinal haemorrhage with varied results (2).

On a molecular and genetic level, the disease process leading to the clinical manifestations of BRBNS is poorly understood. Although BRBNS develops sporadically in most cases, it is sometimes inherited in an autosomal dominant pattern (chromosome 9p) (5). A locus on the same gene has also been associated with familiar venous malformations and it has been hypothesised that BRBNS may be a subset in the general category of familial venous malformations (5). In patients with BRBNS, the c-kit (a stem cell growth factor receptor, previously described with respect to angiogenesis) was found in smallsized vessels within the specimens of a patient with BRBNS (7). This would suggest that this particular signalling axis is involved in the constant growth of the venous malformations.
Thus, targeting slowly cycling endothelial cells using c-kitspecific inhibitors might represent a novel therapeutic option for BRNBS (7).

Operative management certainly poses a significant challenge in these patients and the risk of significant haemorrhage is not to be underestimated. Appropriate counselling to the patient and/or their relatives must be carried out. A detailed radiological examination of the soft tissue vasculature around the proposed operative field must be performed. The intracranial vasculature should also be investigated pre-operatively with at least an MR venogram. This may provide one with an idea of the importance of the soft tissue vasculature serving as a drainage conduit for the intracranial venous sinuses, thereby anticipating operative hazards in preparation. Additional haemostatic aids, as used for this patient, must be available in the operating room for efficient control of torrential bleeding.

We would also recommend pre-operative consultation with a haematologist with regards to carrying out appropriate haematological investigations, and the use of pre-operative interferon or steroids may be a useful adjunct in optimising this patient for an operation.

\section{REFERENCES}

1. BeanWB:Blue rubber-bleb nevi of the skin and gastrointestinal tract. In: Bean WB. Vascular spiders and related lesions of the skin. Springfield, IL: Charles C Thomas, 1958:17-185

2. Boente MD, Cordisco MR, Frontini MD, Asial RA: Blue rubber bleb nevus (Bean syndrome): Evolution of 4 cases and clinical response to pharmacologic agents. Pediatr Dermatol 16(3): 222-227, 1999

3. Deng $\mathrm{ZH}, \mathrm{Xu} C D$, Chen $\mathrm{SN}$ : Diagnosis and treatment of blue rubber bleb nevus syndrome in children. World J Pediatr 4(1): 70-73, 2008

4. Gabikian P, Clatterbuck RE, Gailloud P, Rigamonti D: Developmental venous anomalies and sinus pericranii in the blue rubber-bleb nevus syndrome. Case report. J Neurosurg 99(2): 409-411, 2003

5. Gallione $\mathrm{CJ}$, Pasyk KA, Boon LM, Lennon $\mathrm{F}$, Johnson DW, Helmbold EA, Markel DS, Vikkula M, Mulliken JB, Warman ML: A gene for familial venous malformations maps to chromosome $9 p$ in a second large kindred. J Med Genet 32:197-199, 1995

6. Kunishige M, Azuma H, Masuda K, Shigekiyo T, Arii Y, Saito S: Interferon alpha-2a therapy for dissemination intravascular coagulation in a patient with blue rubber bleb nevus syndrome. A case report. Angiology 48(3): 273-277, 1997

7. Mogler C, Beck C, Kulozik A,Penzel R, Schirmacher P, Breuhahn $\mathrm{K}$ : Elevated expression of $\mathrm{c}-\mathrm{kit}$ in small venous malformations of blue rubber bleb nevus syndrome. Rare Tumors 2(2):e36, 2010 